\title{
Circumstances When Arterial Blood Gas Analysis Can Lead Us Astray
}

In this issue of Respiratory CARE, Van de Louw et $\mathrm{al}^{1}$ describe the magnitude of spurious hypoxemia as suggested by arterial blood gases (ABGs) obtained from subjects with acute leukemia and hyperleukocytosis. Spurious hypoxemia, commonly known as leukocyte larceny, is just one of several erroneous values or discrepancies with pulse oximetry and the bedside assessment (or bioassay) that may occur when obtaining or interpreting ABGs. What follows is a short description of these other common pitfalls, including pre-analytic issues such as syringe material, sample volume, and non-blood contaminating solutions, as well as more clinically oriented aspects such as barometric pressure, temperature, and hemoglobin ligands. Rapid recognition of these inaccuracies or confounders can minimize mistaken conclusions and improve patient care.

It is paramount to eliminate erroneous values when assessing a patient's oxygenation, ventilatory, or acid/base status, and several important pre-analytic steps must be followed in order to obtain a valid, interpretable ABG. The first is to verify that the values make sense and fit the HendersonHasselbalch equation, $\mathrm{pH}=\mathrm{pKa}+\log \left(\mathrm{HCO}_{3}{ }^{-} / \mathrm{CO}_{2}\right)$, for acid/base values and that $\mathrm{P}_{\mathrm{aO}_{2}}$ does not yield negative or irrational alveolar $\mathrm{P}_{\mathrm{aO}_{2}}$ differences as calculated by the alveolar gas equation, $\mathrm{P}_{\mathrm{aO}_{2}}=(\mathrm{Patm}-\mathrm{PH} 20) \mathrm{F}_{\mathrm{IO}_{2}}-\left(\mathrm{P}_{\mathrm{aCO}} / \mathrm{R}\right)$. Admittedly, using the Henderson-Hasselbalch equation can be tedious; however, there is a modified version of the Henderson-Hasselbalch equation that can be quite useful: 1) calculate the hydrogen ion concentration using the equation $\left[\mathrm{H}^{+}\right]=24 \times \mathrm{P}_{\mathrm{CO}_{2}} / \mathrm{HCO}_{3}{ }^{-}$, with $\mathrm{P}_{\mathrm{CO}_{2}}$ given in $\mathrm{mm} \mathrm{Hg}, \mathrm{H}^{+}$as nanomolar, and $\mathrm{HCO}_{3}{ }^{-}$as millimolar; 2) use the calculated $\left[\mathrm{H}^{+}\right]$to determine what the $\mathrm{pH}$ should be, since $\mathrm{pH}$ is a function of hydrogen ion concentration $\left(\left[\mathrm{H}^{+}\right]\right.$of $25 \mathrm{nM}$ correlates to $\mathrm{pH}$ of $7.60,\left[\mathrm{H}^{+}\right]$of $40 \mathrm{nM}$ correlates to $7.40,\left[\mathrm{H}^{+}\right]$of $63 \mathrm{nM}$ correlates to 7.20 , etc.); 3 ) compare the calculated $\mathrm{pH}$ with the measured $\mathrm{pH}$, and if there is a discrepancy there is probably a measurement

The authors have disclosed no conflicts of interest.

Correspondence: Tyler J Albert MD, Veterans Affairs Puget Sound Health Care System, 1660 S. Columbian Way, S-111-PULM, Seattle, WA 98108. E-mail: Tyler.Albert@va.gov.

DOI: $10.4187 /$ respcare.04556 or transcription error. Performing these simple calculations before interpreting a blood gas can help to detect mistaken entries or erroneous values and avoid the interpretation of confusing results.

\section{See the Original Study on Page 8}

Procuring samples using suitable syringes filled with adequate amounts of blood without air bubbles, maintaining them at correct temperatures, and transporting them appropriately for rapid analysis can each help to minimize erroneous values. Several studies have sought to determine the effects of syringe material (plastic vs glass), storage time, and storage temperature on normal ABG and blood oxygen saturation values. ${ }^{2,3}$ Results suggest that samples drawn into plastic syringes should be analyzed immediately, that on-ice storage of plastic syringes is ineffective, and that if analysis is going to be delayed, samples should be drawn and stored in glass containers. Although values can change with time in both glass and plastic syringes, errors are most prevalent and consequential when used to calculate the alveolar-to-arterial oxygen difference using the alveolar gas equation. Combined errors with the $\mathrm{P}_{\mathrm{aCO}}$ and $\mathrm{P}_{\mathrm{aO}}$ are additive as the sample gains some oxygen and losses $\mathrm{CO}_{2}$ to the ambient air.

Other sources of erroneous values include abnormal or misstated $\mathrm{F}_{\mathrm{IO}_{2}}$, barometric pressures, or temperatures at the time of blood draw. If the $\mathrm{F}_{\mathrm{IO}_{2}}$ and barometric pressure are different from 0.209 or $760 \mathrm{~mm} \mathrm{Hg}$, respectively, results may suggest a spurious hyperoxemia or hypoxemia. Stating the patient's temperature is equally important because blood gas analyzers measure samples at $37^{\circ} \mathrm{C}$. If the patient is hypothermic, the $\mathrm{P}_{\mathrm{aO}}$ and $\mathrm{P}_{\mathrm{aCO}}$ will be spuriously elevated. The opposite is true in the case of hyperthermia, because it causes a spuriously low $\mathrm{P}_{\mathrm{aO}_{2}}$ and $\mathrm{P}_{\mathrm{aCO}}$. This occurs due to the influence of heat on both the carbonic acid $\left(\mathrm{HCO}_{3}{ }^{-}+\mathrm{H}^{+} \rightarrow \mathrm{CO}_{2}+\mathrm{H}_{2} \mathrm{O}\right)$ and oxyhemoglobin equilibria $\left(\mathrm{HbO}_{2} \rightarrow \mathrm{Hb}+\mathrm{O}_{2}\right)$, driving both reactions to the right and thus increasing the partial pressures of dissolved $\mathrm{CO}_{2}$ and $\mathrm{O}_{2}$.

Sample dilution can be an additional source of error, with both liquid heparin and saline as potential culprits. Heparin has been used for more than half a century in preparing samples for blood-gas analysis because com- 
pletely anticoagulated samples are essential for testing parameters such as $\mathrm{pH}, \mathrm{P}_{\mathrm{aCO}}$ and $\mathrm{P}_{\mathrm{aO}_{2}}$. Unfortunately, heparin can lead to some erroneous values as well, through dilution of blood when liquid heparin, as opposed to dried (lyophilized) heparin, is used. ${ }^{4}$ Although there is a considerable difference in $\mathrm{pH}, \mathrm{P}_{\mathrm{CO}}, \mathrm{HCO}_{3}{ }^{-}$, and $\mathrm{P}_{\mathrm{O}_{2}}$ of liquid heparin (or saline or other fluids used to maintain indwelling catheters that is inadvertently taken into the sample when not enough dead space volume is cleared) when compared with arterial blood, the $\mathrm{pH}$ and $\mathrm{P}_{\mathrm{O}_{2}}$ of the blood sample remain relatively constant (due to the high $\mathrm{O}_{2}$ and $\mathrm{H}^{+}$buffering capacities of hemoglobin that resist changes when $\mathrm{H}^{+}$or dissolved oxygen are altered). The same cannot be said about dissolved $\mathrm{CO}_{2}$ and $\mathrm{HCO}_{3}{ }^{-}$, however, because both fall in direct proportion to the extent of dilution. ${ }^{5,6}$ This results in a spurious mixed metabolic acidosis and respiratory alkalosis with a normal $\mathrm{P}_{\mathrm{aO}_{2}}$ and $\mathrm{pH}$ but depressed $\mathrm{P}_{\mathrm{aCO}_{2}}$ and $\mathrm{HCO}_{3}{ }^{-}$. Dilution is also a reason why sample volume is also a possible source of error. Studies suggest that samples of $<1.8 \mathrm{~mL}$ (when using a 3 -mL syringe) may provide inaccurate results. ${ }^{7}$

Even the mode of sample transportation to the laboratory for analysis has been assessed, with results revealing worse interference from air contamination after pneumatic tube system transport as compared with manual transport of the specimen, especially in the presence of inadvertent air bubbles. ${ }^{8}$ Inadvertent or unrecognized exposure to air can lead to $\mathrm{CO}_{2}$ loss and diagnosis of an apparent in vivo alkalosis. Fortunately, this is not often an issue, particularly with small air bubbles $(<5-10 \%$ of the total volume if expelled at the time of sampling) and samples that are not shaken or expelled too quickly. The American Association for Respiratory Care guidelines detail these current best practices for sampling, handling, and analyzing ABGs. ${ }^{9}$

As Van de Louw et $a^{1}{ }^{1}$ describe in their recent article, leukocyte larceny is another possible etiology of spurious results, specifically spurious hypoxemia. This effect can be seen not only with extreme leukocytosis (white blood cells $>100 \times 10^{9} / \mathrm{L}$ ) but with extreme thrombocytosis (platelets $>100 \times 10^{10} / \mathrm{L}$ ) as well, due to ex vivo oxygen consumption by these metabolically active cells. Importantly, extreme leukocytosis and thrombocytosis only lead to spurious hypoxemia and not spurious hypercarbia due to the considerably higher $\mathrm{CO}_{2}$ buffering capacity of blood.

It is worth touching upon discrepancies that can occur between $\mathrm{P}_{\mathrm{aO}}$ and direct oximetry saturations, because there are several physiological and clinical conditions that can lead to these differences. Temperature, which was briefly touched upon above, is an important variable in regard to oxygen saturation, with hypothermia causing higher (and hyperthermia causing lower) $\mathrm{O}_{2}$ saturations than would be expected for any given $\mathrm{P}_{\mathrm{aO}}$. Acid/base disturbances can also lead to $\mathrm{P}_{a O_{2}}-\mathrm{O}_{2}$ saturation discrepancies, with alkalemia causing higher (and academia causing lower) $\mathrm{O}_{2}$ saturations than would be expected.

Finally, differences with hemoglobin can lead to significant $\mathrm{P}_{\mathrm{aO}}-\mathrm{O}_{2}$ saturation discrepancies in 2 specific ways. Different ligands of hemoglobin can lead to spuriously high $\mathrm{O}_{2}$ saturations with present day 2-wavelength pulse oximeters, specifically carbon monoxide $(\mathrm{CO})$ and nitric oxide (NO). $\mathrm{CO}$ binds directly to hemoglobin iron in competition with $\mathrm{O}_{2}$; $\mathrm{NO}$ and other agents oxidize hemoglobin iron from its normal ferrous $(2+)$ state to ferric $(3+)$ state (methemoglobin). In either state $\mathrm{O}_{2}$ can no longer be bound, but as a result, both carboxyhemoglobinemia and methemoglobinemia spuriously elevate the readout of $\mathrm{O}_{2}$ saturation. In the case of $\mathrm{CO}, 2$-wavelength oximeters count carboxyhemoglobin as oxygenated hemoglobin. With methemoglobinemia, the problem is a bit more complex, since the unique absorption spectra of methemoglobin causes 2-wavelength pulse oximeters to read saturations of $80-$ $85 \%$ when methemoglobin concentrations rise to critical concentrations $>20 \%$, independent of the $\mathrm{P}_{\mathrm{aO}}$ or actual methemoglobin value. ${ }^{10}$ Moreover, with both carboxyhemoglobinemia and methemoglobinemia, the remaining ferrous heme-iron groups bind oxygen more avidly, subsequently decreasing the amount of $\mathrm{O}_{2}$ that can be delivered to the tissues. To correctly resolve the spectra and concentration of these other forms of hemoglobin requires multi-wavelength co-oximetry. There are also $>200$ rare different genetic variants of hemoglobin that can lead to $\mathrm{P}_{\mathrm{aO}_{2}}-\mathrm{O}_{2}$ saturation discrepancies. Variants with low partial pressures of oxygen at which the hemoglobin is 50\% saturated $\left(\mathrm{P}_{50}\right)$, such as fetal hemoglobin, cause higher $\mathrm{O}_{2}$ saturations, whereas variants with high $\mathrm{P}_{50}$ values cause lower saturations at any given $\mathrm{P}_{\mathrm{O}_{2}}$.

Last, clinicians should be aware of 2 situations in which arterial $\mathrm{pH}$ and $\mathrm{P}_{\mathrm{CO}_{2}}$ values may seriously fail to reflect the actual state of tissue acid/base status. Central to the basis of using ABG analysis for assessment of respiratory acidosis is the assumption that cardiac output, tissue perfusion, and the high efficiency of blood to carry and transport carbon dioxide as bicarbonate are not compromised. Under these normal circumstances, the usual veno-arterial $\mathrm{pH}$ and $\mathrm{P}_{\mathrm{CO}_{2}}$ differences are 0.05 and $5 \mathrm{~mm} \mathrm{Hg}$, respectively; thus, taking such small differences into account provides one with an almost perfect mirror of tissue status. However, in low flow states, such as in severe congestive heart failure, ${ }^{11}$ decreased blood flow to the tissues and thence to the lungs leads to $\mathrm{CO}_{2}$ retention, which will not be reflected in the arterial blood, which by its passage through the lung will have come into equilibration with alveolar gas and cleared a considerable amount of $\mathrm{CO}_{2}$ from the low flow it received. Depending upon the patient's ability to hyperventilate in response to worsening tissue acid/base status, the arterial blood may even have a 
lower than normal $\mathrm{P}_{\mathrm{CO}_{2}}$ and suggest an erroneous state of respiratory alkalosis. The other situation in which large differences between tissue and arterial blood $\mathrm{pH}$ and $\mathrm{P}_{\mathrm{CO}_{2}}$ can occur is when acetazolamide or any other carbonic anhydrase inhibitor is given in doses $(>500 \mathrm{mg}$ or lesser doses when renal clearance of the drug is impaired) that lead to significant red cell carbonic anhydrase inhibition. ${ }^{12}$ Under these circumstances, the normal capacity of blood to rapidly interconvert $\mathrm{CO}_{2}$ and bicarbonate within the $0.5-1.0 \mathrm{~s}$ of capillary transit in the lungs and tissues disappears, and the ability to use bicarbonate as a transport form of $\mathrm{CO}_{2}$ is lost. Unless one measures tissue $\mathrm{P}_{\mathrm{CO}_{2}}$ or surrogates for it, such as central or mixed venous blood, the presence and magnitude of tissue $\mathrm{CO}_{2}$ retention will go wholly unrecognized.

In summary, there are numerous ways in which erroneous values or oxygen saturation discrepancies can lead to confusing and misleading ABG interpretations. Minimizing errors and recognizing spurious values will help diminish errant conclusions and ultimately improve patient care by avoiding the larceny of excessive cost and even possible harm arising from a mistaken diagnosis.

Tyler J Albert MD Hospital and Specialty Medicine Veterans Affairs Puget Sound Health Care System Seattle, Washington and University of Washington Medical Center Seattle, Washington

Erik R Swenson MD Pulmonary and Critical Care Medicine Veterans Affairs Puget Sound Health Care System Seattle, Washington

\section{REFERENCES}

1. Van de Louw A, Desai RJ, Schneider CW, and Claxton DF. Hypoxemia during extreme hyperleukocytosis: how spurious? Respir Care 2016;61(1):8-14.

2. Wu EY, Barazanji KW, Johnson RL Jr. Sources of error in $\mathrm{A}-\mathrm{aDo}_{2}$ calculated from blood stored in plastic and glass syringes. J Appl Physiol 1997;82(1):196-202.

3. Knowles TP, Mullin RA, Hunter JA, Douce FH. Effects of syringe material, sample storage time, and temperature on blood gases and oxygen saturation in arterialized human blood samples Respir Care 2006;51(7):732-736.

4. Bradley JG. Errors in the measurement of blood $\mathrm{P}_{\mathrm{CO}_{2}}$ due to dilution of the sample with heparin solution. Br J Anaesth 1972;44(2):231232.

5. Hutchison AS, Ralston SH, Dryburgh FJ, Small M, Fogelman I. Too much heparin: possible source of error in blood-gas analysis. BMJ 1983;287(6399):1131-1132.

6. Higgins C. The use of heparin in preparing samples for blood-gas analysis. MLO Med Lab Obs 2007;39(10):16-18, 20.

7. Hedberg P, Majava A, Kiviluoma K, Ohtonen P. Potential pre-analytical errors in whole-blood analysis: effect of syringe sample volume on blood gas, electrolyte and lactate values. Scand J Clin Lab Invest 2009;69(5):585-591.

8. Astles JR, Lubarsky D, Loun B, Sedor FA, Toffaletti JG. Pneumatic transport exacerbates interference of room air contamination in blood gas samples. Arch Pathol Lab Med. 1996;120(7):642-647.

9. Davis MD, Walsh BK, Sittig SE, Restrepo RD. AARC Clinical Practice Guideline: Blood Gas Analysis and Hemoximetry: 2013. Respir Care 2013;58(10):1694-1703.

10. Haymond S, Cariappa R, Eby CS, Scott MG. Laboratory assessment of oxygenation in methemoglobinemia. Clin Chem 2005;51(2):434444.

11. Androgué HJ, Rashad MN, Gorin AB, Yacoub J, Madias NE. Assessing acid-base status in circulatory failure: differences between arterial and central venous blood. N Engl J Med 1989;320(20):13121316.

12. Swenson ER. Safety of carbonic anhydrase inhibitors. Expert Opin Drug Saf 2014;13(4):459-472. 